\title{
Complete sequence and structure of ribosomal RNA gene of Heterosporis anguillarum
}

\author{
Shu-Jen Tsai ${ }^{1}$, Guang-Hsiung Kou ${ }^{2}$, Chu-Fang Lo ${ }^{2}$, Chung-Hsiung Wang ${ }^{1, *}$ \\ ${ }^{1}$ Department of Entomology, National Taiwan University, Taipei 106, Taiwan \\ ${ }^{2}$ Department of Zoology, National Taiwan University, Taipei 106, Taiwan
}

\begin{abstract}
The ribosomal RNA (rRNA) gene region of the microsporidium Heterosporis anguillarum has been examined. Complete DNA sequence data (4060 bp, GenBank Accession No. AF402839) of the rRNA gene of $H$. anguillarum are presented for the small subunit gene (SSU rRNA: $1359 \mathrm{bp}$ ), the internal transcribed spacer (ITS: $37 \mathrm{bp}$ ), and the large subunit gene (LSU rRNA: $2664 \mathrm{bp}$ ). The secondary structures of the $H$. anguillarum SSU and LSU rRNA genes are constructed and described. This is the first complete sequence of an rRNA gene published for a fish-infecting microsporidian species. In the phylogenetic analysis, the sequences, including partial SSU rRNA, ITS, and partial LSU rRNA sequences of the fish-infecting microsporidia, were aligned and analysed. The taxonomic position of $H$. anguillarum as suggested by Lom et al. (2000; Dis Aquat Org 43:225-231) is confirmed in this paper.
\end{abstract}

KEY WORDS: Heterosporis anguillarum $\cdot$ Microsporidium $\cdot$ rRNA $\cdot$ Secondary structure Resale or republication not permitted without written consent of the publisher

\section{INTRODUCTION}

The causal agent behind 'beko disease' afflicting the eel Anguilla japonica is known to be the microsporidium Heterosporis anguillarum which infects the skeletal muscle of the eel. This microsporidium had been assigned to the genus Pleistophora (Hoshina 1951), and it has been suggested that $P$. anguillarum should be transferred to the genus Heterosporis and renamed H. anguillarum (Lom et al. 1989, 2000). Despite the morphological evidence, comparative studies of partial small subunit ribosomal RNA (SSU rRNA) gene sequences of $H$. anguillarum with those of other microsporidia reveal that $H$. anguillarum does not belong to the genus Pleistophora (Nilsen 2000). Hence, the taxonomic position of this microsporidium has been redefined.

A partial SSU rRNA sequence (1183 bp) of Heterosporis anguillarum has been published in a previous study (Hung et al. 1998). Comparison studies and phylogenetic analysis of SSU rRNA gene sequences of fishinfecting and other microsporidia show that they can be

${ }^{*}$ Corresponding author. E-mail: wangch@Ccms.ntu.edu.tw divided into 3 major groups. H. anguillarum is a member of Group III (or Group I: Nilsen et al. 1998) which consists of all the fish-infecting microsporidia, except Nucleospora salmonis, and $H$. anguillarum is not closely related to the Pleistophora species (Nilsen 2000). In contrast to the studies of SSU rDNA, only a few large subunit ribosomal RNA (LSU rDNA) gene sequences and complete rDNA sequences of microsporidia have been reported and compared (Baker et al. 1994, Zhu et al. 1994, de Rijk et al. 1998b, Gatehouse \& Malone 1998, Peyretaillade et al. 1998). In this paper we present a complete rDNA sequence including the SSU rRNA gene internal transcribed spacer (ITS) and LSU rRNA gene from $H$. anguillarum. The sequences, organization, and secondary structure of the $H$. anguillarum rRNA gene are compared and discussed. The phylogenetic relationship of $H$. anguillarum to other fish-infecting microsporidia is also discussed.

\section{MATERIALS AND METHODS}

Spore purification and genomic DNA preparation. Microsporidian spores of Heterosporis anguillarum were 
isolated from Japanese eels with symptoms of 'beko disease'. The purification of spores was carried out as described previously (T'sui \& Wang 1988). The suspension of purified spores $\left(2 \times 10^{7}\right.$ spores in $0.25 \mathrm{ml}$ TE buffer) was mixed with equal volumes of zirconia/silica beads ( $0.1 \mathrm{~mm}$ diameter) in $10 \times$ $75 \mathrm{~mm}$ glass tubes and then shaken at maximum speed on a vortex mixer for 1 min (Undeen \& Cockburn 1989). The DNA was extracted using the QIAamp DNA Mini Kit (Qiagen) according to the manufacturer's instructions. The DNA concentration was counted with a GeneQuant II RNA/DNA calculator (Pharmacia). The DNA was eluted in buffer and stored at $-20^{\circ} \mathrm{C}$ until use.

PCR amplification, cloning and sequencing of the rRNA gene. The genomic DNA (100 ng) was mixed in a $100 \mu \mathrm{l}$ reaction mixture containing $10 \mathrm{mM}$ Tris- $\mathrm{HCl}, \mathrm{pH}$ 9.0, $50 \mathrm{mM}$ $\mathrm{KCl}, 1.5 \mathrm{mM} \mathrm{MgCl}_{2}, 100 \mathrm{mM}$ of each dNTP, $100 \mathrm{pmol}$ of each primer (Table 1), and $2.5 \mathrm{U}$ of Taq DNA polymerase (Promega). The amplification was performed in an AG-9600 Thermal Station (Biotronics) for 40 cycles, each with the following profile: $94^{\circ} \mathrm{C}$ for $0.5 \mathrm{~min}, 50^{\circ} \mathrm{C}$ for $0.5 \mathrm{~min}$, and $72^{\circ} \mathrm{C}$ for $2 \mathrm{~min}$. A $10 \mu \mathrm{l}$ aliquot from each reaction was run on a $1.0 \%$ agarose gel to visualize the PCR products and photographed using the Eagle-Eye II photo-documentation system (Stratagene). The PCR products were cloned into the pGEMT Easy Vector System (Promega). White colonies were selected and both DNA strands of the cloned DNA fragments were sequenced on an automated DNA sequencer (DNA Sequencer 377, Applied Biosystems).

Amplification and sequencing strategy. The primers used for rRNA gene amplification and sequencing are shown in Table 1. The strategy of amplification and sequence is shown in Fig. 1. The complete DNA se- quence of the SSU rRNA gene of Heterosporis anguillarum was amplified using a primer set: $18 \mathrm{f}$ and 1537r (Vossbrinck et al. 1993). The fragment containing ITS was amplified using a primer set: HG4F and HG4R (Gatehouse \& Malone 1998). The amplicon's sizes with these 2 primer sets are shown in Table 1 and Fig. 2A.

The major sequence of the LSU rRNA gene was achieved by sequencing the amplicon of a primer set: LS228F and ILSUR (Table 1, Fig. 2A, Lane 2). Primer LS228F is a complementary sequence of 228r (Vossbrinck et al. 1993), and Primer ILSUR was designed from the highly conservative sequence of the eukaryotic LSU rRNA gene sequence. Six internal sequencing primers were designed for sequencing the LS228F/ILSUR amplicon (Table 1).

The 3' end of the LSU rRNA gene sequence was followed by the single-specific-primer PCR (SSP-PCR) technique (Shyamala \& Ames 1989). Briefly, the Heterosporis anguillarum genomic DNA was doubly

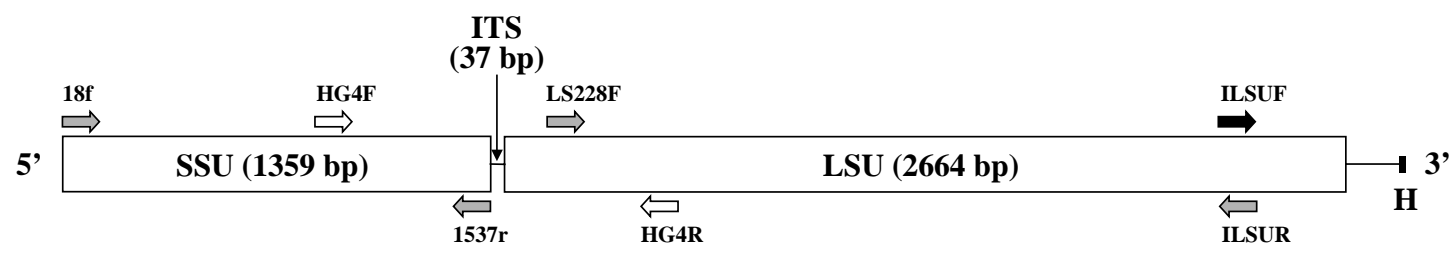

Fig. 1. Heterosporis anguillarum. Schematic diagram of rDNA gene. Mature rRNA domains are boxed. Locations on rDNAs of PCR primers are given in Table 1. The arrows represent the 3 '-end of each primer: the gray-shaded primers produce the major coding regions of rDNA, and the product of the white primers contains the internal transcribed spacer (ITS); the black primer is used as a specific primer for amplifying the 3 '-end of large subunit rDNA. H: HindIII restriction site 
(A)

(B)
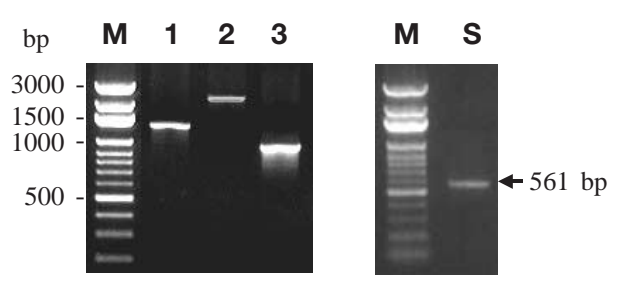

Fig. 2. Heterosporis anguillarum. PCR amplification of rRNA genes and the internal transcribed spacer (ITS) region. (A) Lane 1: small subunit (SSU) rRNA gene was amplified by Primer Set 18f/1537r (1366 bp); Lane 2: main part of large subunit (LSU) rRNA gene was amplified by primer set LS228F/ILSUR (2249 bp); Lane 3: the HG4F and HG4R primers were used to amplify the partial SSU rRNA, ITS region, and partial LSU rRNA genes (1017 bp). (B) Amplification of 3' end of $H$. anguillarum LSU rRNA gene by SSP-PCR. Lane S: PstI + HindIII-digested $H$. anguillarum genomic DNA and pBluescript II SK-vector were ligated and amplified with the Specific Primer ILSUF and Vector Primer T7; arrow indicates the $561 \mathrm{bp}$ DNA fragment; M: Bio100 DNA ladder marker (in A and B)

digested with PstI and HindIII, and ligated to the PstI/ HindIII-digested DNA of pBluescript II SK-vector (Stratagene). The ligated DNA was used as template DNA. The forward primer, ILSUF, was designed from the sequence of the concordant region of Primer ILSUR from the eukaryotic rRNA sequence (Table 1), and the Reverse Primer T7 (5'-TAA TAC GAC TCA CTA TAG GGC-3') was given by the Stratagene company. After PCR amplification, the specific amplicon (Fig. 2B) was obtained and sequenced on an automated DNA sequencer.

Secondary structure construction. The secondary structures of Heterosporis anguillarum rRNA were constructed by a manual and automatic method starting from DCSE alignment files and drawn by RnaViz program (de Rijk \& de Wachter 1997). Using the DCSE alignment editor (de Rijk \& de Wachter 1993), the secondary structures of SSU rRNA (van de Peer et al. 2000) and LSU rRNA (Wuyts et al. 2001) were aligned to the rRNA database. The helices in the rRNA secondary structure elements were localized and given a number in all known eukaryotic rRNA (50 helices in eukaryotic SSU rRNA, A-I regions and hypervariable areas, V1-12 in eukaryotic LSU rRNA).

Phylogenetic analysis. The Heterosporis anguillarum rRNA gene sequence-including partial SSU rRNA, ITS, and partial LSU rRNA, located from position 461 to 1826 (1366 bp) - was aligned with that of the fish-infecting microsporidia (the sequences from GenBank), using the CLUSTAL W program (Thompson et al. 1994). The concordant sequence of Nucleospora salmonis (GenBank Accession No. U78176) was used as an outgroup. Phylogenetic analysis was per- formed using the heuristic search with the maximumlikelihood algorithm with PAUP 4.0b4a (Swofford 1998). One hundred bootstrap replicates were generated to test the robustness of the tree.

\section{RESULTS}

\section{SSU rRNA gene sequence}

The complete DNA sequence of the SSU rRNA gene of Heterosporis anguillarum has been submitted to GenBank, the accession number is AF402839. The SSU rRNA gene contains $1359 \mathrm{bp}$, and the base composition is $54.1 \% \mathrm{G}+\mathrm{C}$. The secondary structure model incorporated in the database for the SSU rRNA of $H$. anguillarum is shown in Fig. 3. This model consists of a core (formed by 1, 2, and 31 helices) and 4 branches (formed by 1-21, 22-30, 32-48, and 49-50 helices) from the $5^{\prime}$ end clockwise to the $3^{\prime}$ end. The helices 10,18 , and 46 were missing, and a helix specific to the eukaryotic model was numbered E23-1 (57 bp) which localized between 23 and 24 helices.

The sequence identity among Heterosporis anguillarum SSU rRNA and other fish-infecting microsporidia (from GenBank) in the Pleistophora group ( $P$. typicalis, P. hippoglossoideos, Pleistophora sp. 2, P. ehrenbaumi, and Pleistophora sp.1; GenBank Accession Nos.: AF044387, AF044388, AF044389, AF044392, and AF044394, respectively) was $91 \%$; Glugea anomola (AF044391), P. finisterrensis (AF044393), Pleistophora sp. 3 (AF044390), and Loma salmonae (U78736) showed homologies of $89,90,90$ and $84 \%$, respectively, and Nucleospora salmonis (U78176) showed only a $61 \%$ homology.

\section{ITS sequence}

The ITS region, localized between SSU and LSU rRNA, contains only $37 \mathrm{bp}$. The base composition of the ITS sequence is $40.5 \% \mathrm{G}+\mathrm{C}$. The sequence identity between Heterosporis anguillarum ITS and other fishinfecting microsporidia was 68 to $71 \%$ homology for the Pleistophora group. Glugea anomola, P. finisterrensis, Pleistophora sp. 3 and Loma salmonae showed homologies of $39,44,44$ and $56 \%$ respectively. Nucleospora salmonis showed only $9 \%$.

\section{LSU rRNA gene sequence}

For sequencing the 3 ' end of the LSU rRNA gene, the PstI site in the sequenced PCR product with a primer set (LS228F and ILSUR) was found. The PstI/HindIII- 


\section{Heterosporis anguillarum SSU rRNA}

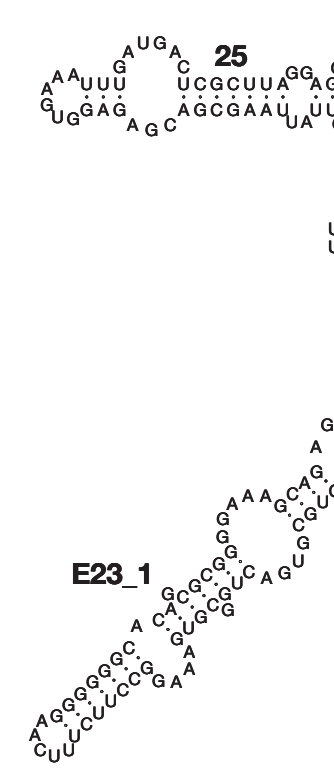

Fig. 3. Heterosporis anguillarum. Secondary structure model for small subunit (SSU) rRNA. The helix numbering system of Neefs
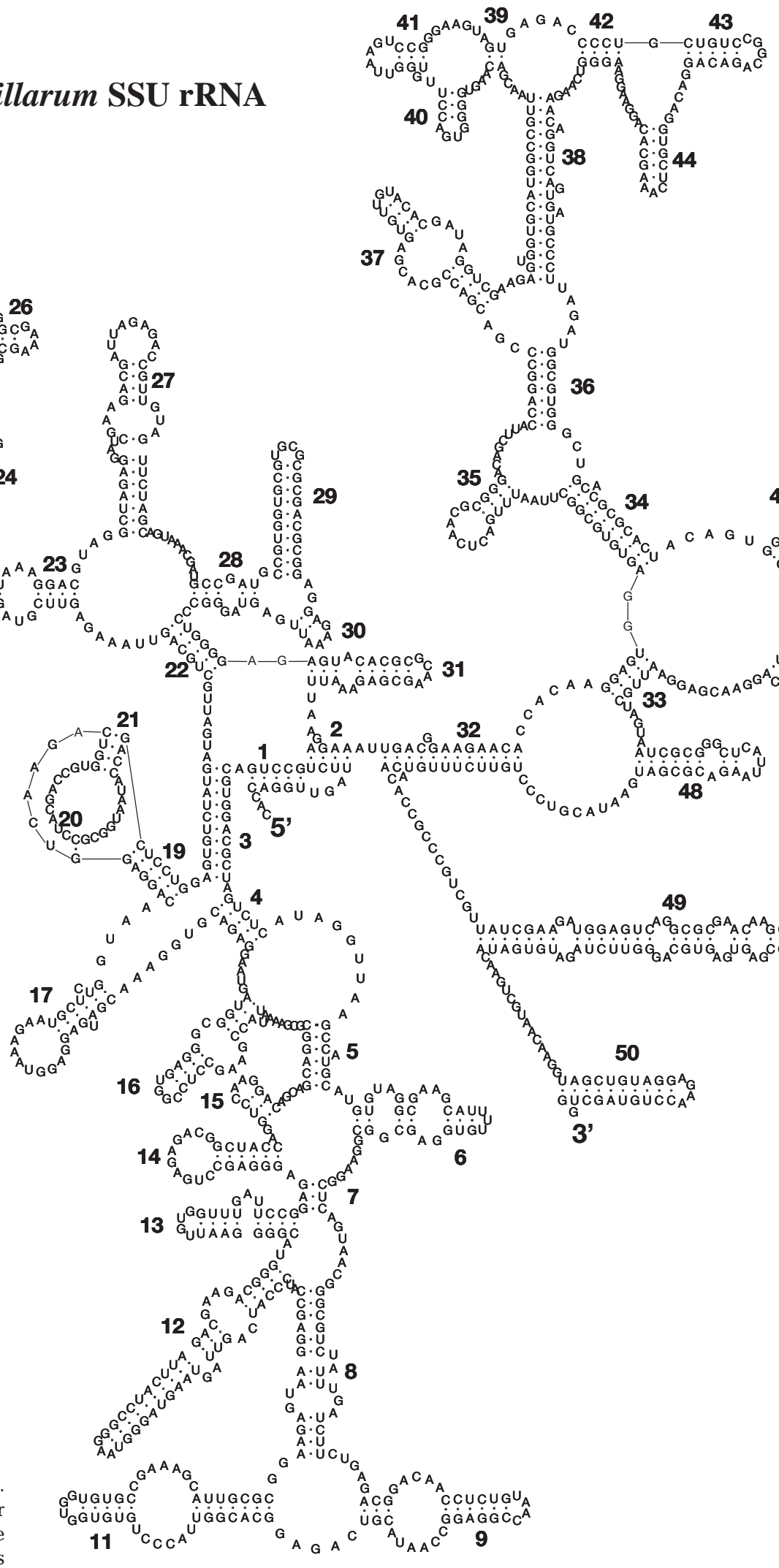
et al. (1993) is employed 


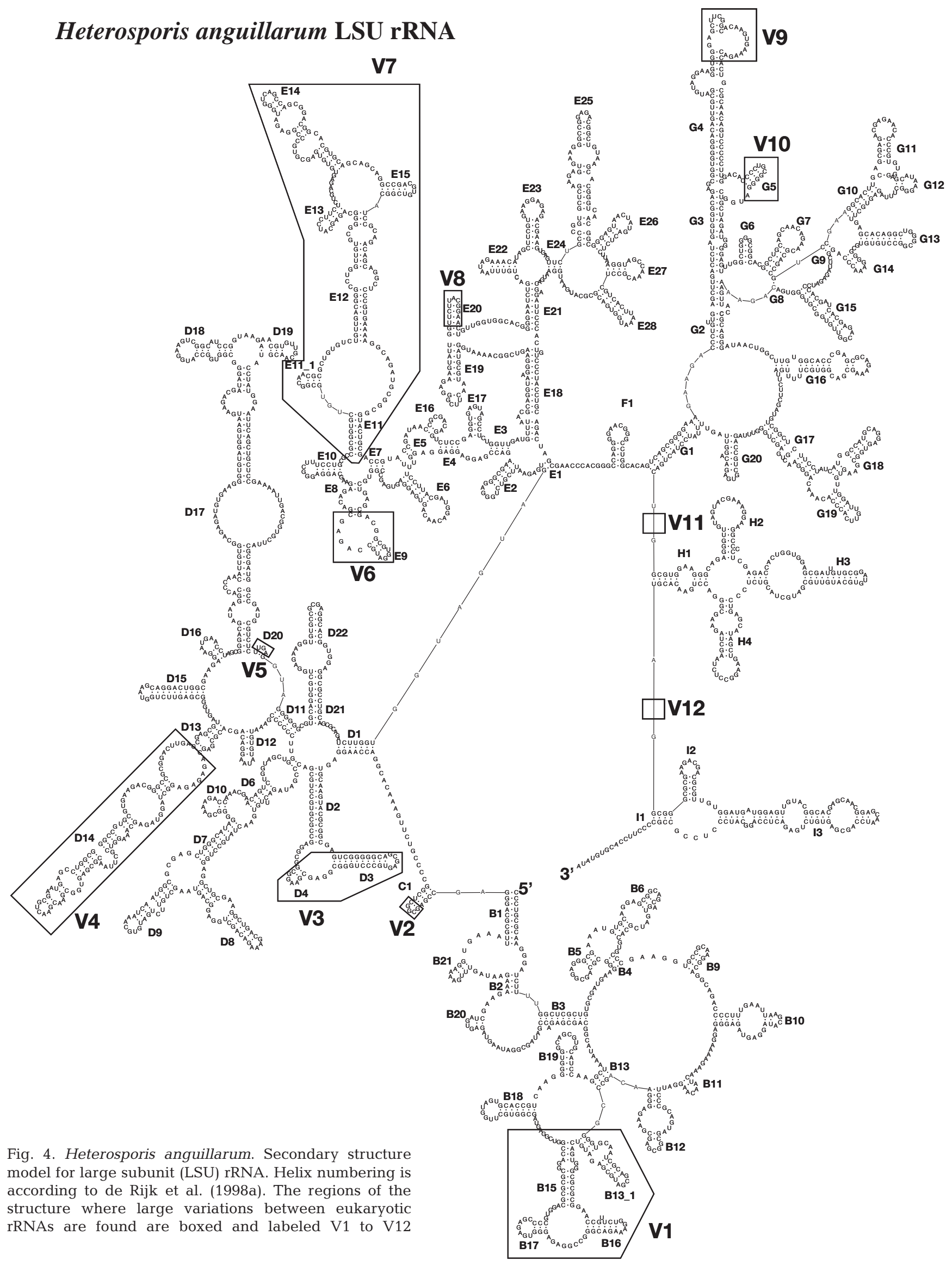


digested genomic DNA was ligated with vector DNA, and this ligated DNA as template DNA with ILSUF and $\mathrm{T} 7$ primers in PCR yielded an amplicon (561 bp) after amplification by SSP-PCR technique (Fig. 2B). By comparison with 3 microsporidian LSU rRNA gene sequences, Nosema apis (de Rijk et al. 1998b, GenBank Accession No. U97150), Microsporidium 57864 (U90885), and Encephalitozoon cuniculi (Peyretaillade et al. 1998, GenBank Accession No. AJ005581), a putative terminal region was identified (Fig. 4).

The secondary structure of the LSU rRNA gene of Heterosporis anguillarum is shown in Fig. 4. The LSU rRNA gene contains $2664 \mathrm{bp}$ and the base composition of the LSU rRNA sequence is $58.9 \% \mathrm{G}+\mathrm{C}$. The secondary structure of the LSU rRNA of $H$. anguillarum is basically similar to that of Nosema apis (de Rijk et al. 1998b). Seven groups (B to I) can be distinguished clockwise from a core area. Fig. 4 also shows 12 hypervariable areas (V1-12); 4 helices (B7, B8, B14, and D5) are missing. Based on the secondary structure of the eukaryotic LSU rRNA (de Rijk \& de Wachter 1997), 4 areas of the hypervariable areas are almost entirely missing (e.g. V2, V8, V10 and V12), and 4 areas are extremely reduced (e.g. V1, V3, V5 and V6).

Due to the lack of complete rRNA sequences among the fish-infecting microsporidia, a comparison of the corresponding LSU rRNA sequences of Heterosporis anguillarum and other fish-infecting microsporidia (from GenBank) was done. The sequence identities between $H$. anguillarum and other fish-infecting microsporidia were 80 to $83 \%$ homology for the Pleistophora group, Glugea anomola, P. finisterrensis, Pleistophora sp. 3 and Loma salmonae showed homologies ranging between 73 and $74 \%$. Nucleospora salmonis showed only $54 \%$.

\section{Phylogenetic analysis}

The phylogenetic tree constructed with data from the Heterosporis anguillarum rRNA sequence including partial SSU rRNA, ITS, and partial LSU rRNA, located from 461 to $1826 \mathrm{bp}$ (1366 bp), was aligned with similar fish-infecting microsporidian sequences obtained from GenBank. The corresponding sequence of Nucleospora salmonis is as an outgroup. The analysis uses the heuristic search with the maximum-likelihood algorithm method. The result is shown in Fig. 5. Except for N. salmonis, the fish-infecting microsporidia belong to Group I based on the SSU rRNA phylogenetic analysis (Nilsen et al. 1998). The members of Group I can be split into 2 subgroups: Subgroup I includes Glugea anomala, Pleistophora finisterrensis and Pleistophora sp. 3, and Subgroup II includes $H$. anguillarum and the Pleistophora group (P. ehren- baumi, P. hippoglossoideos, P. typicalis, Pleistophora sp. 1 and Pleistophora sp. 2) (Nilsen et al. 1998). Loma salmonae is a unique species.

\section{DISCUSSION}

Microsporidia are obligate intracellular parasites lacking mitochondria. The identification of the microsporidian genus and its species has traditionally relied on key characters of host origin, morphology, and developmental cycles by light and electron microscopic studies (Sprague 1977, Canning \& Lom 1986). Some seem to have little or no value in taxonomic identification, especially for closely-related species which lack morphological and life cycle data, due to the fact that the rRNA gene exists in multiple copies in eukaryotic and prokaryotic cells. The rRNA components of eukaryotes and prokaryotes differ in the gene organization and size. The nucleotide sequences of rRNA genes contain highly variable and conserved regions that provide a means for analyzing phylogenetic relationships over a wide range of taxonomic levels. Microsporidia are extremely ancient eukaryotes, and the present prokaryote-like features in their rRNA gene organization and sequence has been reported

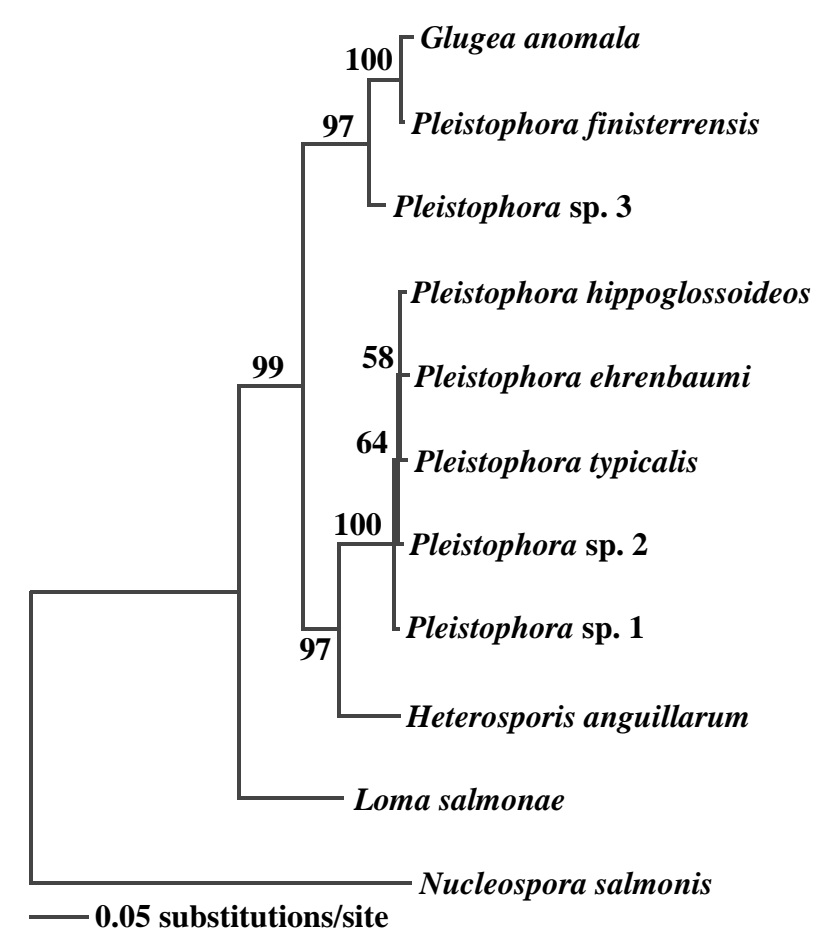

Fig. 5. Maximum likelihood tree obtained by PAUP 4.0b4a Numbers of changes are indicated by the length of the bars. Numbers on the bars indicate percentage of bootstrap replicates containing that topology. The tree is rooted using Nucleospora salmonis as an outgroup 
(Vossbrinck et al. 1987, Galtier \& Gouy 1995). No distinct 5.8S rRNA gene has been found in any reported microsporidian rRNA gene (Vossbrinck \& Woese 1986, Gatehouse \& Malone 1998), and the sequences of microsporidian rRNA are shorter than the known sequences of eukaryotic or prokaryotic rRNA (de Rijk et al. 1998a). We found these characteristics also in the Heterosporis anguillarum rRNA sequence.

The microsporidian rRNA sequences, especially the SSU rRNA sequences, are chosen to investigate the taxonomic position and phylogeny of microsporidia species (Vossbrinck et al. 1987, 1993, Visvesvara et al. 1994, Baker et al. 1995, Malone \& McIvor 1996, Pieniazek et al. 1996, Nilsen et al. 1998, Gresoviac et al. 2000). In this paper, we edited the reported sequence (17 revised bases) (Hung et al. 1998, GenBank Accession No. U47052) and carried out the complete sequence of rRNA gene of Heterosporis anguillarum. For phylogenetic analysis, this sequence was aligned with other known microsporidian SSU rRNA gene sequences of species that infect the muscles of fishes (Nilsen et al. 1998, Nilsen 2000). Nilsen et al. (1998) suggested that the classification of the genus Pleistophora needed re-evaluation and that the insect-parasitizing Pleistophora spp. are not related to the true pleistophoran parasites in the skeletal muscles of fish. Microsporidia can be divided into 2 groups, Group I consists of most fish-infecting microsporidian species. $H$. anguillarum belongs to Group I but is not a member of the Pleistophora group. Later, Nilsen (2000) compared the SSU rRNA sequences from 7 fish-infecting species with those from other microsporidia sequence data. He suggested again that microsporidia can be divided into 3 groups: the species of the Pleistophora group and $H$. anguillarum belong to Group III, previously Group I (Nilsen et al. 1998). In this study, we realigned $H$. anguillarum and 10 fish-infecting microsporidia based on their sequences, including SSU rRNA, ITS and LSU rRNA. Our results support the conclusions of Nilsen et al. (1998). These fish-infecting microsporidia (except for Nucleospora salmonis, the other 10 are Group I of Nilsen et al. 1998) can be divided into 2 subgroups; both $H$. anguillarum and the Pleistophora group belongs to the same subgroup (Subgroup II). This result reconfirms that $H$. anguillarum, while closely related, is not a member of the Pleistophora group.

SSU and LSU rRNA genes are highly conserved among species, while ITS is highly variable rRNA with a high rate of evolution. With these characteristics, ITS sequences are frequently used to clarify the taxonomic position and phylogenetic relationship of species. Among 5 species of the Pleistophora group, the sequences of 2 genes and ITS showed a high homology (above $92 \%$ ). Comparing the rRNA sequence homol- ogy of Heterosporis anguillarum and the Pleistophora group, we found that ITS (68 to $71 \%$ homology) and LSU rRNA (80 to $83 \%$ homology) had a much lower homology than SSU rRNA (90 to $91 \%$, data not shown). These data make clear that the SSU rRNA gene has a much lower evolutionary rate than ITS or the LSU rRNA gene. With an attempt to clarify the relationship of $H$. anguillarum and other fish-infecting microsporidian species, we re-constructed a phylogenetic tree based on the sequence including the SSU rRNA gene, ITS and the LSU rRNA gene. Unfortunately, only 3 complete LSU rRNA gene sequences of microsporidia -Encephalitozoon cuniculi (Peyretaillade et al. 1998), Microsporidium 57864 (GenBank Accession No. U90885), and Nosema apis (de Rijk et al. 1998b) — have been published. With only limited available data of the complete sequences of microsporidian rRNA, only partial sequences of rRNA were used for this study. However, the phylogenetic tree of microsporidia should be reconstructed after more complete sequences of microsporidian rRNA are published.

Because RNA molecules form a structure of helical regions interspersed with single stranded areas, the secondary structure of RNA molecules can be helpful to fine-tune the alignment of sequences for phylogenetic studies (de Rijk \& de Wachter 1997). In this study, we constructed the secondary structures of Heterosporis anguillarum SSU and LSU rRNA and compared their structures with the published data (de Rijk \& de Wachter 1997, Wuyts et al. 2001). Although the available data are limited, we found that several helices can be used for identification or phylogenetic studies: 11, 17, E23-1, 43 and 45 helices for SSU rRNA, V3, V4 and V7 regions and B6, B21, and G5 helices for LSU rRNA. In fact, many microsporidian SSU rRNA sequences have been reported, so the comparison of the secondary structure of SSU rRNA needs to be elucidated further. While only 4 microsporidian LSU rRNA sequences (including $H$. anguillarum LSU rRNA) have been reported, it is difficult to compare the secondary structures of LSU rRNA. However the secondary structure of the rRNA sequence will provide an easy way to clarify or discriminate the taxonomic position and phylogenetic relationship of microsporidia.

Acknowledgements. This paper was supported by the National Science Council, ROC (Grant No. NSC 89-2311-B002-091). We would also like to thank Dr J. Wuyts, University of Antwerp, Belgium, for his assistance with the secondary structures.

\section{LITERATURE CITED}

Baker MD, Vossbrinck CR, Moddox JV, Undeen AH (1994) Phylogenetic relationships among Vairimorpha and Nosema species (Microspora) based on ribosomal RNA sequence data. J Invertebr Pathol 64:100-106 
Baker MD, Vossbrinck CR, Didier ES, Maddox JV, Shadduck JA (1995) Small subunit ribosomal DNA phylogeny of various microsporidia with emphasis on AIDS related forms. J Eukaryot Microbiol 42:564-570

Canning EU, Lom J (1986) The microsporidia of vertebrates. Academic Press, New York

de Rijk P, de Wachter R (1993) DCSE, an interactive tool for sequence alignment and secondary structure research. Comput Appl Biosci 9:735-740

de Rijk P, de Wachter R (1997) RnaViz, a program for the visualization of RNA secondary structure. Nucleic Acids Res 25:4679-4684

de Rijk P, Caers A, van de Peer Y, de Wachter R (1998a) Database on the structure of large ribosomal subunit RNA. Nucleic Acids Res 26:183-186

de Rijk P, Gatehouse HS, de Wachter R (1998b) The secondary structure of Nosema apis large subunit ribosomal RNA. Biochim Biophys Acta 1442:326-328

Galtier N, Gouy M (1995) Inferring phylogenies from DNA sequences of unequal base compositions. Proc Natl Acad Sci USA 92:11317-11321

Gatehouse HS, Malone LA (1998) The ribosomal RNA gene region of Nosema apis (Microspora): DNA sequence for small and large subunit rRNA genes and evidence of a large tandem repeat unit size. J Invertebr Pathol 71: 97-105

Gresoviac SJ, Khattra JS, Nadler SA, Kent ML, Devlin RH, Vivares CP, de La Fuente E, Hedrick RP (2000) Comparison of small subunit ribosomal RNA gene and internal transcribed spacer sequences among isolates of the intranuclear microsporidian Nucleospora salmonis. J Eukaryot Microbiol 47:379-387

Hoshina T (1951) On a new microsporidian, Plistophora anguillarum n. sp., from the muscle of the eel, Anguilla japonica. J Tokyo Univ Fish 38:35-49

Hung HW, Lo CF, Tseng CC, Peng SE, Chou CM, Kou GH (1998) The small subunit ribosomal RNA gene sequence of Pleistophora anguillarum and the use of PCR primers for diagnostic detection of the parasite. J Eukaryot Microbiol 45:556-560

Lom J, Dykova I, Korting WH, Klinger H (1989) Heterosporis schuberti n. sp. a new microsporidian parasite of aquarium fish. Eur J Protistol 25:129-135

Lom J, Dykova I, Wang CH, Lo CF, Kou GH (2000) Ultrastructural justification for the transfer of Pleistophora anguillarum Hoshina, 1959 to the genus Heterosporis Schubert, 1969. Dis Aquat Org 43:225-231

Malone LA, McIvor CA (1996) Use of nucleotide sequence data to identify a microsporidian pathogen of Pieris rapae (Lepidoptera, Pieridae). J Invertebr Pathol 68:231-238

Neefs JM, van de Peer Y, de Rijk P, Chapelle S, de Wachter R (1993) Compilation of small ribosomal subunit RNA structures. Nucleic Acids Res 21:3025-3049

Nilsen F (2000) Small subunit ribosomal DNA phylogeny of microsporidia with particular reference to genera that infect fish. J Parasitol 86:128-133

Nilsen F, Endresen C, Hordvik I (1998) Molecular phylogeny of microsporidians with particular reference to species that infect the muscles of fish. J Eukaryot Microbiol 45:535-543
Peyretaillade E, Biderre C, Peyret P, Duffieux F, Metenier G, Gouy M, Michot B, Vivares CP (1998) Microsporidian Encephalitozoon cuniculi, a unicellular eukaryote with an unusual chromosomal dispersion of ribosomal genes and a LSU rRNA reduced to the universal core. Nucleic Acids Res 26:3513-3520

Pieniazek NJ, da Silva AJ, Slemenda SB, Visvesvara GS, Kurtti TJ, Yasunaga C (1996) Nosema trichoplusiae is a synonym of Nosema bombycis based on the sequence of the small subunit ribosomal RNA coding region. J Invertebr Pathol 67:316-317

Shyamala V, Ames GF (1989) Genome walking by single-specific-primer polymerase chain reaction: SSP-PCR. Gene (Amst) 84:1-8

Sprague V, Vavra J (1977) Classification and phylogeny of the Microsporidia. In: Bulla LA, Cheng TC (eds) Comparative pathobiology. II. Plenum Press, New York

Swofford DL (1998) PAUP*, Phylogenetic analysis using parsimony $\left({ }^{*}\right.$ and other methods), Version $4.0 \mathrm{~b} 4 \mathrm{a}$. Sinauer Associates, Sunderland, MA

Thompson JD, Higgins DG, Gibson, TJ (1994) CLUSTAL W: improving the sensitivity of progressive multiple alignment through sequence weighting, position-specific gap penalties and weight matrix choice. Nucleic Acids Res 22: $4673-4860$

T'sui WH, Wang CH (1988) On the Plistophora infection in eel. I. Histopathology, ultrastructure and development of Plistophora anguillarum in eel, Anguilla japonica. Bull Inst Zool Acad Sin (Taipei) 27:159-166

Undeen AH, Cockburn AF (1989) The extraction of DNA from microsporidia spores. J Invertebr Pathol 54:132-133

van de Peer Y, de Rijk P, Wuyts J, Winkelmans T, de Wachter R (2000) The Europen small subunit ribosomal RNA database. Nucleic Acids Res 28:175-176

Visvesvara GS, Leitch GJ, da Silva AJ, Croppo GP and 7 others (1994) Polyclonal and monoclonal antibody and PCRamplified small-subunit rRNA identification of a microsporidian, Encephalitozoon hellem, isolated from an AIDS patient with disseminated infection. J Clin Microbiol 32: $2760-2768$

Vossbrinck CR, Woese CR (1986) Eukaryotic ribosomes that lack a 5.8S RNA. Nature 320:287-288

Vossbrinck CR, Maddox JV, Friedman S, Debrunner-Vossbrinck BA, Woese CR (1987) Ribosomal RNA sequence suggests microsporidia are extremely ancient eukaryotes. Nature 326:411-414

Vossbrinck CR, Baker MD, Didier ES, Debrunner-Vossbrinck, BA, Shadduck JA (1993) Ribosomal DNA sequences of Encephalitozoon hellem and Encephalitozoon cuniculi: species identification and phylogentic construction. J Eukaryot Microbiol 40:354-362

Wuyts J, de Rijk P, van de Peer Y, Winkelmans T, de Wachter R (2001) The European large subunit ribosomal RNA database. Nucleic Acids Res 29:175-177

Zhu X, Wittner M, Tanowitz HB, Cali A, Weiss LM (1994) Ribosomal RNA sequences of Enterocytozoon bieneusi, Septata intestinalis and Ameson michaelis: phylogenetic construction and structural correspondence. J Eukaryot Microbiol 41:204-209

Submitted: April 2, 2001; Accepted: November 20, 2001 Proofs received from author(s): May 13, 2002
Editorial responsibility: Wolfgang Körting, Hannover, Germany 